\title{
Negotiating Multiple Identities of Brazilian Paralympians
}

\author{
Lyusyena Kirakosyan (D)
}

check for

updates

Citation: Kirakosyan, Lyusyena. 2021. Negotiating Multiple Identities of Brazilian Paralympians. Social Sciences 10: 305. https://doi.org/ 10.3390/socsci10080305

Academic Editor: Sawitri Saharso

Received: 12 June 2021

Accepted: 11 August 2021

Published: 13 August 2021

Publisher's Note: MDPI stays neutral with regard to jurisdictional claims in published maps and institutional affiliations.

Copyright: (C) 2021 by the author. Licensee MDPI, Basel, Switzerland. This article is an open access article distributed under the terms and conditions of the Creative Commons Attribution (CC BY) license (https:// creativecommons.org/licenses/by/ $4.0 /)$.
Virginia Tech Institute for Policy and Governance, Blacksburg, VA 24061, USA; Lyusyena@vt.edu

\begin{abstract}
In this article, I draw on the personal narratives of 41 Brazilian Paralympic athletes who competed in the 2016 Rio Paralympic Games to explore their multiple identities shaped within and outside sport and how they negotiated those self-representations. Parathletes' narratives gave a sense of who they are, how they live their lives, and what their struggles, hopes, and aspirations are within and outside sport. The available studies in disability sport and the representation of disabled athletes have largely failed to examine the stories of these individuals and address their unique realities and perspectives. Five major themes emerged from the interview analysis regarding the parathletes' self-representation: athletic identity, gender identity, disability identity, national identity, and activist identity. These accounts also revealed how these individuals negotiated their multiple identities in different settings and the tensions they experienced in their social interactions. The Rio Paralympics presented such a new interaction setting for the Brazilian parathletes who competed on such a grand scale at home for the first time and provided multiple examples in the athletes' accounts of their identities.
\end{abstract}

Keywords: Paralympic sport; identity; gender; disability; national belonging; activism

\section{Introduction}

The study of sport has stimulated substantial academic interest among sociologists, historians, economists, and political scientists. However, such an interest in disability sport, particularly in Paralympic sport, has been far slower to develop and arguably remains significantly underdeveloped (Thomas and Smith 2009). Moreover, research investigating the influence of sport on disabled athletes' sense of self and identity development is limited (Pack et al. 2017).

Paralympic sport has done a great deal to improve perceptions of disabled people and their achievements in sport and beyond (Jefferies et al. 2012; Kavanagh 2012; Le Clair 2011). However, because of the language barrier, among other reasons, Latin American achievements and challenges in sport are relatively invisible within the academic enterprise dominated by publications and international exchanges in the English language. A great majority of the available studies in Paralympic sport that this article draws upon have been set in the British, Australian, Canadian, and US contexts.

There is also limited empirical research on disability sport in Latin America (Cottingham et al. 2015). Therefore, in this study, I specifically focus on the experiences of the Brazilian Paralympians to bring visibility to their experiences and issues and address a lack of research attention to the different aspects of their identities in Latin America (D'Amico and Benn 2016).

The purpose of this inquiry is two-fold: first, to illuminate the views and experiences of Brazilian Paralympians that shaped the different dimensions of their narrative identities; second, to better understand how these individuals negotiated their multiple identities in different settings and the tensions they experienced in their social interactions. Consequently, the following main questions guided this study:

- How do parathletes see themselves through their different experiences inside and outside Paralympic sport? 
- How did the parathletes' personal experiences and stories clash with the existing social norms regarding gender, sport, disability, and the body?

- What was the impact of the Rio Paralympics on their identities and personal experiences? What was the personal meaning of this Paralympics to the interviewed?

These questions address several concerns that Seal (2014) raised some years ago when arguing that the available studies in disability sport and the representation of disabled athletes have largely failed to examine the stories of these individuals and address their unique realities and perspectives. Foregrounding the unique and individual experiences and identities of Paralympic athletes can help generate resistance to the prevailing narratives they encounter in their daily interactions and recognize these individuals' embodied experiences as part of a holistic understanding of disability sport (Seal 2014).

\section{Research Design and Methods}

As a narrative inquiry, this study placed people, their lived experiences, and personal identities at the center, inviting the development of interpretive methodologies since while telling their stories, individuals interpret and give meaning to the experiences captured by those stories (Bochner and Riggs 2014).

\subsection{Data Collection}

The research project was reviewed and approved by the Virginia Tech Institutional Review Board in July 2016, then, in January 2017, by the Paralympic Academy of the Brazilian Paralympic Committee. The Academy gave me access to the coaches of Paralympic sports, who subsequently served as my points of contact with parathletes. Some coaches shared all active athletes' emails and phone numbers, while others chose who I could talk to and directed me to those athletes.

The individual semi-structured interviews took place in Portuguese, in person, over the phone, or through voice calls on Skype and WhatsApp, between March and June 2017, within a year after the Rio 2016 Paralympics. Each interview lasted between $40 \mathrm{~min}$ and an hour. I recorded the interviews with the athletes' consent, transcribed them in Portuguese, and translated the selected passages to English. With their permission, I refer to the interviewed by their first names to address the issue of anonymity and the hypervisibility of disability that Peers (2009) claimed often surrounds their identities and accomplishments.

The interviews were underpinned by open-ended exploratory questions, through which I sought to gather diverse perspectives, encouraging respondents to offer their own definitions and meanings of their experiences. More specifically, sample interview questions included the following:

- How did you get involved in Paralympic sport? How do you see sport's impact on you, your life, and your identity?

- How do you see disability?

- How do you describe/interpret your experiences at the Rio Paralympic Games? Have you participated in the Paralympic Games before? What did they mean to you personally? Would you please share some stories/examples that have arisen from your experience?

- In your view, have the Paralympics served as a source of positive imaging of people with disabilities in Brazil? If yes, in what ways?

- What were your perceptions of the media portrayal of the Rio Paralympics?

- What were the greatest challenges you faced before and at the Rio Games? How did you address them and who did you involve?

\subsection{Study Participants}

Before this study, I had seen some of the interviewees in the media during the Rio Paralympics, but I had not personally met them. Their careers evolved at a critical time in 
the Brazilian Paralympic movement culminating in their participation in the 15th Summer Paralympic Games in Rio de Janeiro.

I interviewed 41 parathletes (21 male and 20 female) representing 11 Paralympic individual and team sports. They had visual and physical impairments and different periods for the onset of impairment: few had congenital conditions, while the majority acquired visual or physical impairments later in life. Their age ranged between 18 and 45. Twenty-four of the interviewees practiced team sports (sitting volleyball-11 athletes, wheelchair rugby -5 , adaptive sailing - 2, and goalball-6), and the remaining 17 practiced individual sports (Paralympic judo - 2 athletes, athletics-3, swimming-3, wheelchair fencing-2, shooting sports-3, powerlifting-2, and table tennis-2). For $40 \%$ of the interviewees, Rio Paralympics was the first such mega-event in their lives, while 60\% competed in the previous editions of the Summer Paralympic Games.

\subsection{Data Analysis and Interpretation}

After transcribing and organizing the interview texts, an initial reading of all the material helped me get a general idea of participants' accounts. Subsequently, as a third step, I undertook a more detailed analysis with a coding process for which I used a combination of predetermined and emerging codes. Predetermined codes were based on the reviewed literature: for example, sports hierarchy; impairment hierarchy; gender stereotypes; disability stereotypes; fair/unfair treatment; barriers in sport; and public attitudes. Emerging codes arose from the interviews: for example, the perceived lesser appreciation of Paralympians than Olympians; self-responsibility and individualization; the perceived difference in recognition of individual and team sport athletes; genderspecific challenges; self-acceptance and other-acceptance; and stereotypes of femininity. Both types of codes helped develop and refine the analytical ideas, generating themes through the process of "categorizing the categories."

The subsequent thematic analysis enabled me to observe and discern patterns within data to construct meanings and relationships between the categories that led to a more interpretive understanding of different identities. For example, the themes of overcoming, individual responsibility to succeed in sport, lack of appreciation by the media and the general public, and perceived differences in recognition of individual and team parathletes were grouped under athletic identity. Under this construct, the athletes reflected and assigned meanings to their role as an athlete and their relationship with their peers, the media, and the general public.

Five major constructs emerged from the interviews regarding the parathletes' sense of self and self-representation: athletic identity, gender identity, disability identity, national identity, and activist identity. Before examining these constructs, I next survey the main points of discussion in the relevant literature on identity and narrative and current debates in disability studies and disability sport to lay the foundation for the subsequent analysis. This literature review helps situate the study's aims and provides a theoretical lens through which to analyze and interpret the narrative accounts and experiences.

\section{Theoretical and Contextual Background}

\subsection{Identity and Narrative}

According to Jenkins (2014), the notion of identity involves processes of categorization and meaning-making that necessarily invoke two criteria of comparison between persons or objects: similarity and difference. Jenkins warned that simply emphasizing difference will not provide us with proper account identities. He further argued that "identity can only be understood as a process of 'being' or 'becoming'" and thus, it is "never a final or settled matter." (p. 17) Such understanding of identity as a flexible construct resonates with Garland-Thomson's (2002) observation that "disability ... undermines our fantasies of stable, enduring identities in ways that may illuminate the fluidity of all identity." (p. 20)

Several scholars emphasized the role of narratives in the process of identity creation and transformation (Collins 2003; Engel and Munger 2007; McAdams and McLean 2013). 
McAdams and McLean (2013) put forth a concept of "narrative identity" that synthesizes the autobiographical past with the envisioned future creating a coherent account of identity and providing a person's life with a certain degree of unity, purpose, and meaning. Similarly, Engel and Munger (2007) viewed narrating stories about the self as the device everybody uses to make sense of their life experiences through assembling the pieces of their reconstructed past into a coherent narrative that explains who they are. Research demonstrates that the narrator's finding a positive meaning to suffering or adversity is associated with higher levels of happiness, maturity, and well-being, featuring themes of personal agency and exploration in their life story (McAdams and McLean 2013).

Disability studies scholars have understood the importance of the concept of narratives and narrative inquiry to explore identity in various contexts (Seal 2014). Such understanding may be due not only because narratives ensure that the voice of participants is properly heard but also because different levels of narrative allow for a dynamic process of identity construction (Collins 2003). Moreover, as the prevailing cultural narratives of disability denote prejudice, oppression, and disempowerment (Garland-Thomson 2005), self-exploration by the individuals with and without impairments may help produce lessons and insights that McAdams and McLean (2013) believe will enrich a person's life in the long run.

\subsection{Empowerment and Portrayal of Athletes with Impairments}

The debates around the empowerment or disempowerment of athletes in Paralympic sport are closely linked to how the media, sponsors, Paralympic movement, and the general public perceive them (Braye 2016; Hilgemberg 2019; Lindemann and Cherney 2008; Purdue and Howe 2012; Silva and Howe 2012; Stevenson 2010). Parathletes are often portrayed as "supercrips" or "superheroes," a stereotype of someone who heroically overcame his/her impairment and achieved unlikely success (Silva and Howe 2012). When uncritically interpreted, such a narrative seems positive and contesting the widespread negative views of disability. The celebration of this narrative in Paralympic sport may serve the individuals placed on the podium well. Still, such stereotypes may lead to the disempowerment of other athletes with invisible or less severe impairments.

Purdue and Howe (2012) explained that these athletes are caught in the so-called "Paralympic paradox," a situation where they are pressured to showcase their athleticism to able-bodied audiences while restraining their disability identities. Simultaneously, parathletes need to perform as disabled athletes to disabled audiences to show solidarity with these diverse communities. Such dual role of parathletes represents the complexity of Paralympic sport and lies at the heart of the tension between the desired reception from both disabled and nondisabled spectators. As a result, this "paradox" illustrates the challenging nature of any empowerment athletes might achieve in the Paralympic Games since their bodies and their performances are controlled through these tensions and complexities (Seal 2014).

While several scholars argued for the empowering nature of Paralympic sport, Purdue and Howe (2012) posed essential questions to consider before one claims that Paralympians could feel empowered by their sporting achievements and physical capabilities. Does a parathlete's empowerment detach them from other individuals with impairments not involved in Paralympic sport? Furthermore, is there a risk that Paralympians' achievements, if framed within the narrative of overcoming adversity through self-determined effort, will eventually disempower individuals who call for broad societal change? Alternatively, do parathletes and the Paralympic Games provide an avenue for disability rights advocates to broadcast their messages to a wider audience? (Purdue and Howe 2012, p. 915). These questions are considered in the discussion of multiple identities.

\subsection{Conceptions and Disability and Impairment}

The prevailing models of impairment and disability have often been based on a personal tragedy view and associated with stigma and victimization (Kavanagh 2012; 
Le Clair 2011; Silverman and Cohen 2014; Swain and French 2000). Many disability scholars and practitioners located the field's theoretical diversity along a continuum bounded by the "medical model" and the "social model."

In the medical model, the lives of people with impairments are equated with tragedy and dominated by a vast army of medical professionals, who are in an exclusive position to provide a "solution." The medical model is very much prevalent and infused throughout media representations, language, cultural beliefs, research, policy, and professional practice, and often internalized by the individuals with impairments themselves (Swain and French 2000). While many impairments can hardly be medically eradicated, they nevertheless can be rendered less threatening and less limiting through carefully crafted social-psychological interventions (Silverman and Cohen 2014). Conversely, the social model regards disability as a result of the way society is organized, erecting attitudinal, environmental, and institutional barriers. These barriers make it difficult for disabled individuals to take charge of their lives and imply the need for laws that address them.

However, not all people with a disability internalize negative self-conceptions, as the proponents of the medical model argued. Instead, some individuals embrace their impairment as an opportunity and refuse to link it negatively to self-esteem (Hardin 2007). Such a position resulted in developing an "affirmative model" that directly challenges assumptions of personal tragedy and the determination of identity through the value-laden presumptions of nondisabled people. Unlike the social model, the affirmative model is borne of disabled people's experiences as valid individuals, determining their lifestyles, culture, and identity. The discussion of these models is relevant and essential in the studies of disability sport. Non-tragic self-representations and self-awareness of athletes, as discussed later, may positively contribute to group identity and be helpful in the struggle against oppression and discrimination.

\subsection{Gender Stereotypes, Inequality, and Discrimination}

Although the institution of sport is a "masculine construction," sport does not construct gender, race, sexuality, and class in a simplistic, functionally reproductive manner. Organized sport, disability sport included, has only reinforced the ideologies of white middle-class masculine superiority over women and race- and class-subordinated men (Dworkin and Messner 2002). There is compelling evidence that disability strongly impacts gendered experience and affects men and women differently: the collision between masculinity and disability may create an erosion of masculine status, while the stereotypes of femininity and disability converge in their characteristics of vulnerability, dependency, and objectification (Manderson and Peake 2009; Nolan 2013).

Patterns of masculinity are socially defined in contradistinction from models of femininity, whether real or imaginary (Connell and Messerschmidt 2005), including their disabled versions. For disabled men, participating in sport can be communicating invulnerability, which transforms the stigma associated with their condition and creates a space for rehabilitating their masculinity (Lindemann and Cherney 2008). Although there is a nucleus of disabled women who are keen sportswomen and have reached an elite level, research shows that most disabled women prefer non-competitive recreational activities rather than competitive sport (Hargreaves 2000).

\subsection{Case Studies in Specific Sports}

Several studies explored the abovementioned issues in the context of specific Paralympic sports, for some reason limited to wheelchair sports:

- Powerchair football (Richard et al. 2017);

- $\quad$ wheelchair basketball (Hardin 2007; Hodges et al. 2014; Ruddell and Shinew 2006);

- wheelchair rugby (Gard and Fitzgerald 2008; Lindemann and Cherney 2008);

- wheelchair tennis (Kavanagh 2012); and

- wheelchair athletics (Howe 2011; Manderson and Peake 2009). 
These case studies discussed the issues of gender relations and disability, the role of technology in Paralympic sport and the athlete's identities in specific sports. A "mixed blessing" of technology in Paralympics, in Howe's (2011) view, may empower some athletes, especially those from the West, while leaving others at a disadvantage, especially those from the developing world without performance-enhancing technology at their disposal.

I found no research that examined the experiences and self-representation of Paralympic athletes in the context of multiple sports or that discussed the relevant issues comparing individual and team sports. Parathletes in this study represent 11 individual and team sports in Brazil's Paralympic universe. The narratives below, organized around five identity categories, help reveal both the commonality of the experiences and perspectives across individual and team sports as well as the differences between them, and advance our understanding of their collective identity.

\section{Discussion of Identities}

Research in psychology found that performing multiple identities can provide an individual with greater psychological well-being and benefits such as opportunities for social interaction, economic mobility, and the accumulation of skills and abilities if the identities are in harmony with each other (Pack et al. 2017). Discussing multiple identities of Paralympians shows their numerous roles and group memberships with which they identify and find meaning.

\subsection{Athletic Identity}

Athletic identity is the extent to which individuals identify with the role of an athlete (Pack et al. 2017). It allows Paralympians to become role models to empower the wider population with impairments (Purdue and Howe 2012). However, in the case of Brazilian parathletes, serving as positive sporting and lifestyle role models is not limited to individuals with impairments. It includes individuals without impairments as well, particularly school and college youth. As some interviewees noted, they have used their influence to enact positive change, which is related to their activist identity discussed later. The athletic identities of Brazilian Paralympians featured the following four major themes: overcoming adversities, self-responsibility and individualization, lack of appreciation of parathletes, and perceived differentiated recognition of individual and team sports athletes.

\subsubsection{Overcoming Adversities}

The theme of overcoming and the related portrayal of parathletes as superheroes was one of the main topics that emerged from the interviews. Regardless of accepting or resisting the stereotypes of parathletes as overcoming adversities, the participants were unanimous in rejecting the superhero label. They viewed the superhero label linked to their impairments that undervalued their sporting performance.

For a long time, I thought that the word "overcoming" should not be applied to Paralympic sport. We are not a model for overcoming simply for having an impairment. When you have a social reality that is unfavorable to your accomplishment, you have probably overcome the expectations. I think it is more appropriate to use the term [overcoming] in the sense of living in a nation that hasn't considered disabled people as capable of working and living a full life as any other human being. In elite Paralympic sport, we overcome the inappropriate attitudes, not our impairments. (Edenia, swimming)

The title of a superhero seems like an obligation. Every athlete is potentially a superhero because we do extraordinary things. But it's not because of our impairment that we are superheroes because we overcame it. It's the overcoming of an athlete, pushing the boundaries as high-performance athletes. We don't want to be victims because we are capable. [ ... ] But we are also not superheroes just because we have physical limitations. (Lucia, judo) 
In these excerpts, the parathletes discuss two notions of overcoming. They support the kind of overcoming that Purdue and Howe consider inherent within high-performance sport, as athletes pursue their next classification, next medal, or record (Purdue and Howe 2012). However, the athletes were critical of the kind of overcoming that relates to their impairment or disability, which frames it as "an individual matter that is personal responsibility" and can be "a very lonely task that rarely requires adaptation by the able majority but can constitute a significant change for a person with an impairment." (Silva and Howe 2012, p. 179)

The distorted tendency to either "undervalue" or "overvalue" achievements of those with impairments has low social expectations at its heart (Silva and Howe 2012). Such "super" descriptions seem to reinforce differences holding the individuals to whom they are applied as someone extraordinary, which may justify the public's admiration for those who overcome adversities. Furthermore, such "super" or "incredible" representations of parathletes seem to place the responsibility for success on the individuals themselves, without considering other favorable or unfavorable factors that shaped those accomplishments (Silva and Howe 2012).

\subsubsection{Self-Responsibility and Individualization}

Many athletes emphasized individual responsibility to succeed in sport and in life in general, which is one of the critical values of neoliberalism. The neoliberal ideology of self-responsibility places both the merit of success and the burden of failure on isolated individuals and suggests that resolving every social issue requires the further individualization and financialization of social policies (Fine and Saad-Filho 2017). Research pointed out a problem with the success stories in disability sport, as they raise unrealistic expectations of what disabled people should achieve and perpetuate an idea of "overcoming" that disregards the complexities associated with disability experiences (Seal 2014).

Many people discuss the issue of inclusion in disability sport. Everybody has their own prejudices. We, people with impairments, need to be self-reliant and break the barriers and move ahead. I believe that sport is a tool for inclusion, be that sport for leisure, competitive, or elite sport. (Laiana, sitting volleyball)

I was firmly committed to competing in the Rio Paralympics, and it came at a price. I was not present in my family's life and became a visitor in my own home because I had to train and travel to the international competitions. [ ... ] Often, even as a member of the national team, I had to pay my travel expenses to compete internationally, 10-12 thousand reals [approximately 3-4 thousand U.S. dollars in 2017] at a time, because I had my goal [to participate in the Paralympics], and I had to do my part. (Sandro, wheelchair fencing)

The neoliberal notions underpinning the parathletes' experiences direct their focus on working on "the self" rather than attempting to improve the social context or remove structural constraints disabled people might face. Moreover, neoliberal ideals behind such statements encourage people to do it alone to prove that they are "responsible citizens" who can take care of themselves without the government's assistance, thus creating new expectations concerning the relationship between the well-being of individuals, their families, and the population.

\subsubsection{Lack of Appreciation of Paralympic Athletes}

Several parathletes indicated they experienced a frequent lack of appreciation by the media and the general public. The passages below and findings by other scholars (Jefferies et al. 2012) explain that Paralympic athletes consider a range of motivating factors in their performances, from their desire to achieve the best sports results and represent their country to feeling challenged and recognition as elite athletes by others. However, insufficient recognition may adversely impact athletes and their careers, especially when the financial support to Paralympic sport is insufficient and they are forced to earn a living through other means. 
It happened to me a few times when I wore the national team uniform. I heard people commenting on the street, "Look, there is a national team athlete; go talk to him." And as soon as people saw that I was not an Olympic but a goalball athlete, a lesser-known sport, their interest visibly diminished. Now and then, I still come across such situations. (Zé Roberto, goalball)

When I was in London [in 2012], I noticed that they had a different view of Paralympic sport there. I saw outdoors featuring Olympic and Paralympic athletes together. They also have different sport investment policies there, which make a greater recognition of Paralympic sport possible. In Brazil, before the Paralympics, when I would tell people that I was a Paralympic athlete, they would ask, "Para what?" ["para que?" in Portuguese, literally meaning "what for?"]. People did not even know there was a Paralympic movement. [...] We do not have this culture of appreciating and recognizing Paralympic sport as a whole. (Bruno, powerlifting)

Similar to Purdue and Howe's (2012) notion of the "Paralympic paradox" explained earlier, Braye (2016) noted that while the Paralympics has been marketed as a sports event, it is also associated with disability that connects it with society's charitable values. Consequently, the athletic identity of a Paralympic athlete may be considerably overshadowed by people's philanthropic value judgment. The exceptional achievements of disabled athletes are negated by this view, making emancipation of the population with impairments problematic: "This dichotomy of the Paralympic product and the social construction of disability means that this relationship meets at a point where sport sells and disability collects." (Braye 2016, p. 1290) However, when members of society see disability as a tragedy, lack awareness or recognition of Paralympic sport, and undervalue the achievements of its athletes, there may be little to sell or to collect.

\subsubsection{Perceived Differences in Recognition of Individual and Team Parathletes}

In addition to the lack of appreciation and recognition of parathletes, there seems to be a hierarchy between individual and team Paralympic sports. While the interviewees did not use these terms, their explanations of the perceived differences appeared to express the neoliberal logic of "return on investment," where the return is measured in the number of medals, podiums, and classifications. As Andrews and Silk (2018) have noted, "the pervasiveness and the invasiveness of neoliberalism as a structure of feeling has contributed to the semiconscious encroachment of particular values, strategies, and outcomes into the nature and experience of everyday life." (p. 512) These values have shaped the experiences and opportunities of Paralympic athletes in Brazil and elsewhere.

Team Paralympic sport is less acknowledged than individual modalities. You notice that parathletes who compete in individual sports have better visibility with the public, the media, and the Paralympic Committee than those who compete in team sports. It can be because of the number of medals they bring in. For example, in athletics, one can compete in three races and win three medals. In volleyball, we play six games to win one medal. It may be a matter of more return in medals. (Adria, sitting volleyball)

I see that some Paralympic sports enjoy more promotion and visibility than others. For example, blind football is treated with more esteem than goalball. Football is more privileged because it is a popular sport; then judo, for bringing many medals. And goalball was marginalized. Same with athletics, the athletes receive sponsorships from banks, TV broadcasters, and other companies; more always goes to athletics than to goalball. [ ... ] Athletics has more visibility, maybe it generates more interest among private sponsors, and that's why we have this hierarchy of values. (Zé Roberto, goalball)

Many of the team sport athletes I interviewed work full-time in the public or private sector as administrators, IT professionals, or teachers because the financial support for 
being high-performance athletes and part of Brazil's national team was insufficient to provide for their families. They practiced sport at night or on weekends. At the same time, many of the participants in individual sports received enough financial support and proceeds from sponsorships to dedicate themselves wholly to the sport.

Difficulties with sponsorships and financial support varied across sports. While elite Paralympic athletes typically receive support through federal and state grants, these funds were not sufficient for sports equipment acquisition and maintenance. Moreover, federal grants were delayed throughout 2016, with payments restarting in early 2017. As a result, some athletes shared that their peers had to borrow money, crowdfund, or work temporary jobs (for example, drive for Uber) to earn a living and continue training for the upcoming Rio Paralympics.

In sum, the athletic identities of Brazilian Paralympians featured major themes that were underpinned by the neoliberal values and politics of individualization, where stories of sporting success or failure place the merit and responsibility on the individual and establish respective expectations for these and other disabled individuals. Moreover, neoliberal values shape situations where respect for athletes and their accomplishments is measured within a framework of cost-benefit or return on investment. Such dynamics lead to conditions where the potential of Paralympic images to motivate others to engage in sport is undermined and where only a few parathletes become empowered in and through Paralympic sport (Silva and Howe 2012).

\subsection{Gender Identity}

Today, Latin American women participate in all sports. However, many barriers to their participation remain and hold women back, such as affordability and accessibility, coaching, management, and leadership ( $\mathrm{D}^{\prime}$ Amico and Benn 2016). While both mainstream sport and disability sport have continually legitimized the ideology of male superiority and dominance, it is the larger socioeconomic and political context that shapes and constrains the extent to which women can challenge these ways (Kidd 2013). Messner (1992) has rightly argued that simply attempting to incorporate women within the institution of sport that is a "masculine construction," without changing its dominant structure and values, will eventually only reaffirm masculine superiority.

Gender is constructed in and through relations, and patterns of masculinity are socially defined in opposition to the patterns of femininity (Connell and Messerschmidt 2005). Even when female athletes performed exceptionally well, the media attention would be negligible and hardly attracted the interest of the general public and sponsors. Such rare and biased media reports reinforce traditionally unfair female sports coverage and thus also determine the availability of female sports role models and possibilities to challenge existing attitudes (Meier 2015).

Disability and impairments affect men and women differently. Two stigmatized statuses converge in the lives of impaired women, further diminishing their already "devalued gender status." (Gerschick 2000, p. 1265) Conversely, for men with impairments, masculine gender privilege collides with the stigmatized status of having impairments, thereby resulting in status inconsistency (Gerschick 2000). While femininity and disability seem to reinforce each other, disabled masculinity appears to be constructed on the "notion of contradiction." (Manderson and Peake 2009, p. 234) Thus, disabled men can reject the expectations inherent in the "disabled" role by more fully embracing the male gender role (Malhotra and Rowe 2014). Since masculinity is defined as able-bodied and active, becoming disabled for a man means conforming to the stigmatizing constructs of the masculine body made vulnerable (Manderson and Peake 2009).

\subsubsection{Gender Inequality and Bias}

Disability sport, as the mainstream sport, has similar gender inequality issues. A recent study carried out by the Brazilian Institute of Geography and Statistics (IBGE) revealed that only a little over a third of those practicing sport in Brazil are women (IBGE 
2017). Moreover, about $32 \%$ of Brazilian men practice sports and only about $17 \%$ of women (IBGE 2017). While the study did not investigate the practice of sport among Brazilians with impairments, existing research shows that disability and impairment pose additional challenges for the practice of sport, especially for women (Blauwet 2015; Seal 2014). As a female goalball athlete noted, she had some of her competitions canceled because of the insufficient number of female athletes, while her male counterparts did not have such a problem.

I had competitions canceled due to the lack of women in goalball. Worldwide, more nations have national goalball male teams than female teams. In Brazil, too, there are more male than female teams. And although it seems that opportunities are the same, because fewer women engage in sport, we don't have the same competitions that men have. It touches on social issues, such as difficulties of women accessing sport and the stereotype of a blind woman being more fragile. So she goes out less, practices sport less, and is overprotected by her family daily. (Simone, goalball)

A male goalball athlete, who returned from the World goalball championship in 2017, confirmed Simone's evaluation:

In the World Championship from which I just returned, I saw 16 male national teams and only 12 female national teams competing. [ ... ] I have seen some sports clubs prioritizing male goalball and targeting male athletes, but I don't know any entity in Brazil that explicitly targets women to play goalball. Although our Confederation treats both male and female goalball equally, and we receive the same resources, there is still inherent bias associated with the female goalball. (Zé Roberto, goalball)

However, the problem the athletes referred to above is not simply one of allocation, but one of gender bias (Kidd 2013). From the perspective of the feminist critique, sport perpetuates patriarchy by reinforcing the sexual division of labor: "By giving males exciting opportunities, preaching that the qualities they learn from them are 'masculine' and preventing girls and women from learning in the same situations, sports confirm the prejudice that males are a breed apart." (Kidd 2013, p. 556)

Garland-Thomson (2005) has argued that not only do prevailing narratives restrict the lives and govern the bodies of people considered disabled, but they also limit the imaginations of those who think of themselves as nondisabled. These stereotypical narratives ultimately reinforce exclusionary environments, employment discrimination, and social marginalization. As a result, women with impairments have been stereotypically considered in the collective cultural imagination as "inferior, lacking, excessive, incapable, unfit, and useless." (Garland-Thomson 2005, p. 1567) To counter these stereotypes, many women who perform in traditionally male domains focused their efforts on improving "the self" and hold themselves to higher standards, as Debora's quote below illustrates:

Shooting is a male-dominated sport, and I have always felt that. It was not explicit, but I felt that I had to prove that I was better and capable of achieving more. I felt this pressure because I am a woman. When I won in a mixed competition [with male and female participants competing together], men usually joked about the one who lost, "wow, shame on you, you lost to a woman!" I think it exists in the Olympic sport as well; they will always prefer a male athlete. I also think it happens in other countries. I just chose a complicated sport. (Debora, shooting)

Gender bias and stereotyping that Debora and other female parathletes experience are ideological rather than biological. However, they still legitimate an unequal distribution of resources, status, and power within Paralympic sports.

\subsubsection{Gender Stereotypes, Femininity, and Masculinity}

Both within and outside the context of sport, the gendered politics of appearance and systems of beauty standards advance narratives that work to affect disabled women's 
positive body image (Malhotra and Rowe 2014). Similar stereotypes operate in Paralympic sport. Many disabled and nondisabled women are influenced by dominant images of gender, which express commodified anti-athletic stereotypes of femininity. Hargreaves (2000) suggested that some of these stereotypes become internalized and discourage women from participating in sport and perhaps becoming outstanding athletes. The accounts below align with her claim:

After the London Paralympics broadcast on TV, we saw a surge in people's interest in practicing sport. Some girls became interested in sitting volleyball. But after Rio, nobody came looking for sport. It may be to avoid exposure. If a woman doesn't have a leg, she would need to remove her prosthetic leg in front of everyone [on the court, before the game]. And it may discourage some women. Also, many people never practiced sport before their accident or illness, and they may not want to risk and try now. (Suellen, sitting volleyball)

Moreover, having an impairment and being in the world of sport are compounded by gendered barriers related to the patriarchal arrangement of sports (Olenik et al. 1995). Rodrigues (2015) study found that female athletes may walk away from their athletic careers when forced to choose between sport and family. It happens more frequently among female athletes than male athletes. A significant share of the female population internalized heteronormativity and carried on their "natural" roles by prioritizing family and putting aside their professional pursuits. Simone illustrated this problem in the quote below:

In sport, women face prejudice and difficulties in maternity and child-rearing. The sporting milieu is not ready to accommodate a mother-athlete. She will have to take time off if she wants to breastfeed and spend more time with her child. I think there is a possibility of working out strategies that would allow a woman to exercise her professional activity in sport and spend time with her child if there was more sensitivity to this issue. (Simone, goalball)

Acquiring impairment can be a severe crisis for men whose identity construction has been based on physicality and invulnerability, as the collision between masculinity and disability may then create "an erosion of masculine status." (Nolan 2013, p. 593) The following comment helps illustrate how sport can be instrumental in rebuilding an athlete's life and regaining agency and control after injury:

After the accident, after the onset of impairment, one experiences depression. I used to practice sport before the accident, liked sport, and suddenly everything stopped, and you begin mourning. When you get involved in sport, it brings you, let's say, a more colorful life, a better life, overcoming adversities, more than I could imagine. I never expected to compete in the Paralympics, the pinnacle of the elite sport. Better than that would be to win a medal, then you can retire, write a book, and feel accomplished in life. We have a lot of talent in Brazil; one has no way of knowing that he or she can be a future Paralympic champion. (Herivelton, adaptive sailing)

This quote acknowledges the impact of recently acquired impairment and the men's resistance to the construct of disability through embracing the dominant construct of masculinity. In this case, masculinity is reformulated when these men create a personal version of masculinity that they are comfortable with through sports participation. By developing healthy and physically fit bodies and sporting prowess, these men challenge the stereotype of a disabled body as sick, weak, or lacking agency (Manderson and Peake 2009; Stevenson 2010).

[During the Rio Paralympics], people saw how capable we were. We are not some poor souls "playing" sport. They saw how competitive we were. In some sports, we do things that many people without impairment could never do. (Alexandre, wheelchair rugby) 
Rugby has a lot of contact between the wheelchairs, players falling out of their seats. Some people say it is a violent sport and it breaks the stigma even more. I like how sport shows that with or without impairment, we can do anything. (Higino, wheelchair rugby)

As these quotes show, for these men, competitive sport helped bridge the gap between the disabled and nondisabled world and armed them with "a radical critique of the apparent limits of the disabled body and a disruptive break with normative identities." (Manderson and Peake 2009, p. 239) In a similar vein, some participants saw sport as a tool for social change in existing stigmas and stereotypes. Consequently, one's decision to engage in disability sport includes evaluating the subsequent loss/gain in social status (Shuttleworth et al. 2012).

In sum, this discussion sought to explore the intersection of gender and disability in the athletes' self-identities. Two main themes emerged in their narratives and examples: gender bias/inequality and gender stereotypes. The narratives showed that many of their attitudes, beliefs, and self-conceptions became internalized from the ideologies about gender and disability prevailing in the larger society. For male parathletes, the reality of impairment acted as a barrier to their masculinity, as they equated able-bodiedness with the masculine. Impairment forced them to look for ways to reformulate their masculinity through rejecting their disability, and sport served such a goal. In contrast, female parathletes seemed to integrate gender and disability into their athleticism and strived to challenge society's concepts of the ideal body and feminine stereotypes.

\subsection{Disability Identity}

Disability has frequently been regarded as a personal or family problem rather than a matter of societal responsibility. Consequently, disabled people are often expected to overcome barriers to participation by their own extraordinary efforts or rely on their families to provide what they need, usually at great personal sacrifice (Wendell 1989). Silverman and Cohen's (2014) findings underscored the role of the social environment in shaping outcomes for people with impairments. These individuals may struggle to reach their potential if they are surrounded by stigmatization, stereotyping, and discrimination. However, when their environments are characterized by inclusion and acceptance, where an individual is not defined by their impairment but rather seen as a whole and capable person, they can persevere in the face of challenges. Silverman and Cohen (2014) suggested that some limitations posed by physical impairments are social-psychological in their source rather than physical.

\subsubsection{Conceptions of Impairment and Disability}

People with lifelong impairments may learn from an early age to feel comfortable with their identity. In contrast, those who acquire impairments later in life may have already been socialized into the societal norm of stigma and prejudice, resulting in a lack of disability pride (Darling and Heckert 2010). However, assumptions about disability identity are changing, as some of the athletes' narratives below show. The meaning of impairment and disability articulated by athletes rejected the tragic view and recognized the challenges and opportunities they had in life that impacted how they see the world. Although the participants had unique experiences and different impairments and are officially classified as "disabled" athletes for the purposes of Paralympic sport, they did not see themselves as limited or lacking in any sense or think of themselves as disabled. It is also notable that their narratives were not expressed through a dramatic language evocative of loss but instead dealing with the transformation of their bodies as part of personal growth.

It's not easy to live with impairments. But you put in your mind the idea that disability is not death and it's not the end of the pleasure of living, and you can achieve everything you want. (Pamela, sitting volleyball) 
I do not think about what I could not do because of my impairment. I think about what I can do because of it. [...]. Impairment is a peculiarity that will be with me throughout life [...]. I do not see it as a limitation, an impediment. In fact, it is a tool. Without it, I would not be a Paralympic athlete, [...] With it, I am a Paralympic athlete and a more active citizen. (Edenia, swimming)

Disability ends up being a motivation for me to always strive for society's awareness of our existence and less prejudice towards disabled people. Sometimes people ask if I would like to have eyesight. When I was a kid, it was one of my dreams. But today, eyesight will not be among the top 10 things I most want in my life. After all, it does not cause me any difficulty in life. (Zé Roberto, goalball)

Such non-tragic views of disability and impairment frame it as a positive personal and collective identity, in terms of disabled people leading fulfilled lives, or what Swain and French (2000) call "the affirmative model." This model is borne of the experiences of disabled people "as valid individuals, as determining their lifestyles, culture and identity." (p. 578) Although the narratives show that they did not consider impairment and disability in negative terms, they admitted that their self-awareness and self-acceptance developed gradually over time. Sport offered many of them an empowering view of self and often facilitated the acceptance of disability status, as the excerpts below show. Acceptance of the self allowed them to focus on sport and other aspects of their lives, changing their social relations.

After several years of living with an impairment, I graduated with a degree in physical education and specialized in sports training. I started working with people with physical impairments in Manaus, where I live. I went through a recruiting process at the Secretariat [of Education], and I was hired. From there on, I began to accept myself more. (Laiana, sitting volleyball)

After I suffered a motorcycle accident at the age of 20 and lost one leg, I needed a prosthesis and went to the Association for the physically impaired. There, I got to know volleyball through my colleagues. I always liked sport. They introduced me to Guedes [sitting volleyball national team coach]. Sport was vital to me; I felt that I was not alone in that situation. It helped me in my self-acceptance after the accident. I met more disabled people. Then in 2012, I went to my first Paralympics in London. (Jani, sitting volleyball)

Silva and Howe (2012) have alluded to the possible effects of internalized oppression among individuals with impairments, which entail self-beliefs of inferiority, unproductivity, and dependence. Such internalization often results in people settling for less than they can be, achieve, and have. The authors stressed how crucial it was to deconstruct those internalized, distorted self-beliefs and actively encourage people with impairments to participate in areas they have traditionally been underrepresented in, such as sport. However, as Hardin (2007) noted, "not all people with a disability internalize ableism; some embrace their impairment as an opportunity and refuse to link it negatively to self-esteem." (p. 40).

\subsubsection{Disability Stereotypes and Discrimination}

Athletes also talked about negative disability-related stereotypes they face that often lead to prejudice and discrimination. Some athletes stated they had not faced discrimination or barriers, while others shared details about instances that left them frustrated and annoyed by the treatment they viewed as demeaning. Le Clair (2011) suggested that athletes must adopt a specific frame of mind to compete and achieve the goals they have in mind. As a result, they reject the negativity that prejudice and discrimination present and continue working on their goals against the odds.

When my team and I were training in Rio, we had a regatta that was not a Paralympic one. We participated and surprised everybody. We finished first among 50 sailboats. The only disabled crew-it is already a paradigm shift. 
Nowadays, I do not notice much prejudice because I get more involved. I seek to present myself with confidence and show that I have as much capacity as a person without a disability. (Herivelton, adaptive sailing)

I often face prejudice, but it does not affect me anymore. For example, when I travel, I continue working out in local gyms. When I walk in, people already look at me awkwardly. People ask if they can take turns with me on the weightlifting equipment. So we start working out, and they see how much weight I lift and ask, "What do you do? How can you, disabled [dwarf], lift more weight than I do?" Others try to keep up with me and lift the same weight as me, but out of pride, they will not give up, even suffering from pain. They do not want to lose to someone they see as disabled. [ . . . ] Sometimes people come and ask what I do. Nobody even imagines I can be an elite athlete; their prejudice does not let them think it would be possible that a disabled person can be better than them. I do not care anymore; I got used to it. I believe that this discrimination got better after the Paralympic Games. (Bruno, powerlifting)

These excerpts reveal how the interviewees dealt with stereotyping situations in serene ways. Such occurrences did not stop them from engaging in social interactions. Still, research shows that for many people with impairments, perceived attitudes, prejudices, and stereotypes can potentially serve as barriers to social participation and even cause lower well-being (Kavanagh 2012; Silverman and Cohen 2014). As Silverman and Cohen (2014) explained, the more the individuals with impairments are worried about the negative disability-related stereotypes, the more they would attempt to avoid such situations, which in turn may compromise their achievements.

Wendell (1989) also cautioned that in thinking about impairment and disability, one needs to be mindful that society's labels do not always fit the people they are applied to. Consequently, some people who may be perceived as disabled do not experience themselves as such. While physical conditions may be disabling for some, life opportunities and other factors may not significantly limit the activities of others. The use of negative disability stereotypes is more likely to perpetuate existing biases and serve as an impediment to changing existing perceptions and practices.

In sum, two major themes emerged in the disability identity discussion: the meanings that athletes assigned to impairment and disability and negative stereotypes and resulting discrimination. The parathletes differentiated between how they saw themselves (and sought to present themselves) and how they believed the nondisabled society saw them: as weak and inferior victims. Their stories illustrated the contrast between their self-concept as competent and capable and the views of others that then resulted in multiple experiences of discrimination. These stereotypes and instances of discrimination at times (but not always) served to raise awareness about these individuals' capabilities and potentially helped change prevailing perceptions and practices.

\subsection{National Identity}

Sport is considered a significant marker of national identity, and the theme of national belonging became prominent in the narratives of Brazilian parathletes because the Paralympic Games took place in Brazil. Competing at home with full sports venues, thousands of cheering fans, family members, and friends intensified the sense of national belonging. The opportunities for Brazilian parathletes to represent their nation in the Paralympic Games have grown significantly in the last decade, but competing in Rio was a historic moment for them.

Research about how Paralympic athletes are perceived and portrayed in terms of their national belonging is scarce. Braye et al. (2017) have suggested that British Paralympians have rarely been represented as objects of national pride because disability identity may sometimes override national attachment. Furthermore, the authors stated that even in those brief moments when disabled and nondisabled athletes came to share the same space for the sake of "team unity," the evidence suggested that "notions of equality were hollow 
and without substance." (Braye et al. 2017, p. 133) Similarly, Downie and Koestner's (2008) study found that the success of a nondisabled male athlete is more likely to be a source of national pride than the accomplishments of disabled athletes and women.

\subsubsection{Sport and Brazilian National Identity}

For many decades, Brazilian national identity has been closely intertwined with football (soccer) (Guedes 2014; Rubio et al. 2016). Several interviewed parathletes commented on the supremacy of football in the sports arena and the national imagination, describing Brazil as the "land of football" ("terra de futebol" in Portuguese). Guedes (2014) mentioned a quote made by a reporter who summarized the place of sport in Brazil's national identity by claiming that "in Brazil, there are two sports: soccer and whatever's winning." (p. 156) It could be inferred from that statement that any sport can become an object of national pride as long as the participating athletes are victorious in the international competitions: "Sports that create opportunities for international victories are insistently focused on by the media, becoming conversation topics in any social circle." (Guedes 2014, p. 156)

However, currently, the representations of what it means to be Brazilian constitute a whole "inventory of symbols," and new images of Brazil and Brazilians are created (Ortiz 2013, p. 631). The relevance of football to Brazil's national identity has also been declining, bringing material and symbolic changes (Kath and Knijnik 2015). Because national attachments are fluid and their effects are not fixed (Huddy 2016), the declining popular appeal of football opens space for new attachments to emerge.

The interview excerpts below show the sense of national belonging, pride, and honor that the Paralympians felt representing Brazil, some for the very first time, during their respective competitions. Several athletes commented on the personal significance of representing their nation during their first Paralympics and what a motivating force the cheering crowd was for them.

I defended my country; I had the opportunity to be on the national team and participate in big tournaments, making me very proud. [...] Being in the Paralympics seemed like a fairy tale, hard to imagine. It was beautiful, especially in my country, with fans by our side. I felt grateful and proud to defend my country at home and to do what I like. (Bruno, wheelchair rugby)

Brazilians seemed to have identified strongly with Paralympic sport. The Games venues were packed. It was very cool; the Brazilian public's affection was incredible. [...] We in table tennis have never represented Brazil at home before, for me it was very impressive. [...] Before the competition, I thought that since we were the hosts of this tournament, I wanted to give joy to everyone who came to watch. I would be very upset if only Europeans or Asians competed in the quarterfinals or semi-finals, and Brazilian fans would just watch the game. I had a powerful desire to put Brazil in the lead at some point in my class. It was a great accomplishment for me to do that in my country. (Israel, table tennis)

Other athletes expressed how their Paralympic experiences helped foster a shared sense of national identity and unity with other parathletes and the public.

The [Rio] Paralympics was the most significant event I have ever participated in in my life; it was a great opportunity. We in rugby have very few competitions that combine other modalities. And this time we got to know different sports. We all stayed together in the [Paralympic] Village, and everyone there was Brazil. We cheered for each other. There was a lobby where everyone passed through, and TVs were broadcasting all competitions. We would stop to see if there was a Brazilian competing, and we cheered for them, regardless of sport. (Alexandre, wheelchair rugby)

It was essential for me to be a part of this. And the Games itself, what a spectacle! We thought we did not have much prestige, that people would not come and watch us play. Because it would be sad if you play at home and the seats are 
empty, even smaller than the Olympic gymnasiums, I thought to myself, would people come and honor us? But our first game happened in a packed gym. It was terrific; it was such a delight to see our Brazilian people without prejudice. (Laiana, sitting volleyball)

Drawing on existing scholarship, Huddy (2016) claimed that a strong national identity should increase positive feelings for other co-nationals, which in the quote above transcended prejudice. While it may be true that in the Rio sports venues the public actively cheered and supported Brazilian parathletes, it is also true that Paralympians compete for a nation whose members and institutions discriminate against them, as the discussion of disability identity showed. Furthermore, the success of elite Paralympic athletes provides the impression that disability sports institutions and resources are available to all, but it fails to point out that these institutions fail to support many disabled people, especially those with more severe impairments (Braye et al. 2017).

\subsubsection{Patriotic Attitudes}

Many athletes commented on the affection of the cheering crowd in the sporting venues. The quotes below show public attitudes different from those earlier cited by Guedes (2014) that only football and other winning sporting performances could be an object of national pride. These quotes also demonstrate a sense of patriotism seen as positive feelings and a sense of pride in one's country (De Figueiredo and Elkins 2003; Huddy 2016) expressed both by athletes and the crowds cheering for them. Patriotic attitudes convey positive feelings about one's own nation without the derogation towards members of other nations generated by nationalism (De Figueiredo and Elkins 2003). The parathletes felt overwhelmed by the public's patriotic attitudes, as the quotes below attempt to express:

Rio was my first Paralympics. It is difficult to describe the crowd's support, the packed venue, 15-20 thousand people watching. When we play in the local championships, we barely have 100 people watching. It was a unique experience, the crowd cheering for us irrespective of our result. It was incredible. (Higino, wheelchair rugby)

The magnitude of the [Paralympic] event makes you want to be part of history. I don't think we will have another Paralympics in Brazil any time soon. As a Brazilian, I was very proud to be there, to represent my country. The affection of the crowd was the most beautiful thing I have ever seen; it was terrific. (Sandro, wheelchair fencing)

Elite athletes represent their nations in the international competitions all the time, but for this group of athletes, representing Brazil in front of thousands of their compatriots intensified the sense of national belonging and unity. Despite the dominance of football in the national imagination, packed competition venues and cheering crowds at home made parathletes feel that their sporting performances were also objects of national pride. The two themes discussed above, sport and Brazilian national identity and patriotic attitudes, point to changes in the conception of national pride and belonging in Brazil's sport.

\subsection{Activist Identity}

Examining activist identities among elite athletes with impairments is an essential but insufficiently researched subject (Haslett et al. 2020a; Smith et al. 2016). Factors such as widespread stereotypes about disability and a lack of awareness and familiarity with adaptive sports point to the need for disabled athletes to advocate and educate the public (Cottingham et al. 2016). While research on parathlete activism is beginning to grow in countries such as Canada (Bundon and Clarke 2014), the UK (Braye 2016), Ireland (Haslett et al. 2020a, 2020b), and South Korea (Choi et al. 2019), there is a lack of such a body of work in Brazil. This study aims to add to the emerging field by exploring how Brazilian Paralympians approach social activism through Paralympic sport. 
Drawing on existing research in the sociology of sport, Bundon and Clarke (2014) distinguished between two forms of athlete activism: first, instances of broader social injustice (human rights causes based on race, gender, or religious freedoms), and second, actions focused on positive changes in the sport itself (speaking out against gender discrimination or homophobia in sport). However, these scholars have suggested that it would be more productive to think of athlete advocacy as a continuum where athletes move between quieter forms of activism and more politically radical ones. Such a perspective may enable an understanding of how the parathletes' advocacy crosses the border between sport and broader society.

My interviews showed that while all participants identified strongly with athletic identity, not all of them saw themselves as activists or were equally positioned to engage in advocacy projects. Although the connection between sports and activism may not be obvious, sport and the athletic experience may foster progressive social change (Kaufman and Wolff 2010). While it is not imperative that all parathletes should take on activist identities, it is crucial to amplify the voices and stories of those who do (Smith et al. 2016).

Many interviewees shared their efforts to educate people and expose them to the Paralympic sport initiatives, which they considered an effective strategy for enacting change. In their view, the best form of advocacy was being visible and approachable, which may lead to more inclusive environments thanks to casual public interactions between parathletes and others, particularly children and youth. Bundon and Clarke (2014) called this approach "the honey approach," which entails a less confrontational and friendlier strategy. One participant shared his contribution below:

I visited a school where they put disabled and nondisabled students in wheelchairs to play wheelchair tennis, basketball; they also played blind football. It made the kids interested in Paralympic sport. So, when I visited, I talked about my experience, and kids with and without impairments were curious. They can grow up to become future physiotherapists or coach a Paralympic sport. [...] When I meet someone with impairment on the street or public transportation, I want to approach them and ask, "Are you practicing any sport or physical activity? Do you know the benefits it can bring you?" I like using public transportation to meet people, talk to them, tell them they can someday compete in the Paralympics, or just practice sport for leisure and quality of life. I believe I contribute this way through raising awareness, sharing pictures of the sporting events I participate in on my social media accounts to encourage people to challenge themselves and pursue their dreams. (Herivelton, adaptive sailing)

I visit schools and colleges 8-10 times a year, and I consider it very important. It helps break the stereotype of a victim who cannot do anything. They see me arriving in a car, bringing a different kind of wheelchair, showing a video of a game, and it all impacts people. They see wheelchairs clashing, athletes falling, and it changes the paradigm people have about someone with an impairment. (Higino, wheelchair rugby)

Similar to the participants in Malhotra and Rowe's (2014) study, my interviewees were fully aware of their rights and the unfair treatment they experienced at times but found these barriers so common and the process of claiming rights so challenging that they were reluctant to engage in disability rights activism, as the following excerpt shows:

People do not know much about visual impairment or low vision. I face prejudice daily. People see me walking independently, looking at my cell phone screen, and ask why I am standing in a priority line [for senior citizens and those with impairments]. I don't look like someone with impairment, and I was denied service when waiting in the priority line. I had to show my disability card, and the attendant apologized. So I avoid such situations and end up often not claiming my rights. I live my life as a nondisabled citizen. I did not get a free pass, I pay for my bus ride normally, and I avoid waiting in the priority line or sitting 
in the reserved seats [on public transportation for people with impairments]. (Jose Marcio, goalball)

Several athletes I interviewed shared how they have used their platform to promote social missions outside the elite sport.

I visited several schools before the [Rio] Games. When I lived in England, I used to visit schools there too. I am a patron of one school there, Ludworth Primary School in Stockport, Manchester. They made a video for me, wishing me good luck in the Games. They uploaded it to YouTube, [it was] really cool. I also sponsor a project in England called Dream Flight. We raise funds for a year to take 192 children with impairments, at times very severely impaired, to Disneyland in Orlando for ten days. The children travel without their parents, with adult supervision. Their age ranges from 10 to 14 years. We take them on the holiday of a lifetime. During the trip, we explain to children that their impairments are not the end of life, that there is always someone in a worse condition than theirs. We support these children to create courage and take attitudes to do what they want. Because they travel without parents, the children learn to deal with situations independently, of course with our support, but without family overprotection. I love working with kids to plant these seeds in their minds. (Phelipe, swimming)

In Manaus [capital of Amazonas state], I work with five students with impairments in the Military Academy. Our state had two Paralympic medalists, me and Guilherme Costa in table tennis. The authorities began seeing us differently because the medals came from where they least expected. Our Martial Arts Center in the Military Academy has both Olympic and Paralympic modalities. We have blind students practicing judo and jiu-jitsu; you have no idea. [...]. My bronze medal helped me open doors. [...] So, I am trying to use my status as a bronze medalist in this work. (Laiana, sitting volleyball)

A more confrontational advocacy approach, coined by Bundon and Clarke (2014) as "the vinegar approach," was mentioned by one of my interviewees when referring to Fernando Fernandes, a Brazilian Paralympic canoeist and four-time World Champion who did not classify for the Rio 2016 Paralympics. Since 2010, Fernandes had brought visibility to the paracanoeing in Brazil, a few years before it was included in the 2016 Paralympic programming. Later, Fernandes advocated for changes in the current classification system and filed formal complaints on several occasions (O Fuxico 2014; Guimarães et al. 2016).

In sum, it seems that being an advocate is an integral part of many parathletes' public engagement, and they used the platform of sports and their status to promote social missions outside elite sport. While activist engagement did not come up in all interviews, nobody considered activism as incompatible with their athletic identity. Collectively, the participants in this study saw themselves as actively attempting to break down barriers, change attitudes, and create opportunities.

\section{Negotiating Multiple Identities}

The previous section discussed five identity categories that emerged in the narratives of the Paralympic athletes. Based on the experiences and perspectives discussed above, the current section explores how the athletes negotiated their multiple identities in their social interactions.

Swann and Bosson (2008) suggested that identity negotiation processes refer to the activities through which individuals attain a balance between achieving their interaction goals and satisfying their identity-related goals, such as the needs for agency, communion, and coherence. The authors further suggested that in the identity negotiation process, people typically learn to negotiate identities in ways that minimize tensions between their needs in each context. Because identity negotiations routinely occur during daily social interactions wherein many behaviors are automatic, people who engage in identity negotiations may not consciously realize they are doing so. Thus, people may only become 
aware that they want others to recognize and validate a given identity when receiving feedback that suggests that others see them in an identity-discrepant manner. The latter can occur with rapid and unpredicted life changes and new social interaction settings or new negotiation partners. The Rio Paralympics presented such a unique interaction setting for the Brazilian parathletes who competed on such a grand scale at home for the first time. The event provided multiple examples in the athletes' accounts on their identities.

In Swann's and Bosson's framework, while identity negotiation processes entail those activities through which people establish, maintain, and change their identities, it does not explain the subjective value of identity to an individual and what identity will be enacted in his or her social interactions. Here, Brenner et al.'s (2014) examination of the "identity prominence" vs. "identity salience" is helpful for not only a more general understanding of identities but also, in this case, for the continued development of the Paralympic movement and disability sport research.

Drawing on decades of existing research in identity theory, Brenner and colleagues explained that the likelihood of enacting a given identity in social interactions is significantly impacted by the "salience of the identity" relative to the salience of other identities the person holds within a "hierarchy of salience." Another related idea is the "identity prominence" developed by McCall and Simmons (1978) that reflects the individual's subjective sense of the worth of identity to himself or herself. An individual's identity position in the prominence hierarchy may not necessarily align with its position in the salience hierarchy, i.e., a particular identity may be extremely valuable for an individual but not often enacted (Brenner et al. 2014).

Brenner and his colleagues found a strong correlation between prominence and salience, i.e., the higher the placement of identity in the prominence hierarchy, the more the individual will wish to enact it, calling it "a causal pathway from prominence to salience." (p. 234) However, a strong correlation between prominence and salience may vary substantially for other identities or other groups. For example, while athletic identity is both prominent and salient in the narratives of parathletes, it may hold high prominence for an average Brazilian with impairments but not be attractive to practice for personal (e.g., varying types and severities of impairments or low self-esteem or self-confidence) or environmental (e.g., inaccessible transportation or sporting facilities or lack of qualified staff) reasons.

Athletes often negotiated their multiple identities in contradictory and ambiguous ways as they "downplayed" the presence of gender- or disability-related limitations. The narratives revealed that athletic identity was high in the prominence hierarchy. Not only is Paralympic sport an essential part of these individuals' identities and lives, but it is also the most valued activity enacted with much pride and sense of fulfillment, primarily when representing Brazil at the Paralympics in Rio. The participants believed that with the Rio 2016 Paralympics, the public focus started shifting from disability to aptitude in the area they were expected to excel. Their narratives about athletic careers conveyed how sport improved overall quality of life, promoted independence and broader social networks, and encouraged the development of an identity that provided a sense of acceptance, purpose, and pride.

The interview accounts also demonstrated how athletes worked within and around gendered expectations and their disability identity. Malhotra and Rowe (2014) explained that "an individual who fulfills his or her assigned gender role earns the approbation of society and acceptance into the social milieu. An individual who rejects his or her assigned gender role or otherwise fails to perform it is similarly rejected by the society and censured." (p. 153) However, the strategies of male and female parathletes to negotiate their gender and disability identities were different. Female parathletes did not use sport to overcome disability; they instead integrated their disability into their physicality and built up selfesteem, confidence, and self-efficacy to challenge gender stereotypes and encourage other women to do so. While the literature argued that disabled sportswomen feel disadvantaged because they lack power in their relations with nondisabled women, with disabled men, 
with the media, and with disability sports officials (Hardin 2007; Hargreaves 2000), the accounts of this participant group did not frequently reference gender- or disability-related inequalities. Seal (2014) would suggest here that neoliberal politics (and respective values of individualization and self-responsibility) might significantly impact how women negotiate their gender and "disabled" identities and downplay the existence or negative impact of gender barriers in sport.

However, most male parathletes rejected their disability identity to emphasize their gender identity and saw sport as the path to affirming their masculinity. Thus, masculinity had higher prominence for many male athletes, but athletic identity had higher salience because they enacted and affirmed their masculinities through sport. Men who pursue athletic careers are attracted to the idea of sport and its link to developing masculine identities (Messner 1992). For this reason, they seemed to reject disability identity by giving it low prominence and salience because of the social understanding of disability being undesirable. Disabled men's pursuit of respect in sport expresses the "crystallization of the masculine quest for recognition through public achievement." (Messner 1992, p. 56).

When talking about their disability identity, athletes mentioned their own perceptions of, and identifications with, the notions of "normality." These accounts indicated that the participants did not view themselves as having lost something, as being disabled, nor as "supercrips." Yet, many of them felt "different" while growing up and later continued so in the possibilities and perceived hierarchies in sport. Although there are accounts in the literature of a hierarchy of impairments, both for nondisabled people toward different impairment groups and of disabled people also holding differing attitudes toward other impairment groups (Deal 2003), the interview accounts of this group did not reference any hierarchy of impairments. As a group, they claimed that sport gave them opportunities, status, and skills to feel and act "normal," and many female and male Paralympians could frame their disability identity within the affirmative model of disability.

National identities usually received higher prominence when athletes represented Brazil in the international competitions, and the Rio Paralympics stood apart. Showing off their sporting prowess to home crowds in fully packed venues was especially meaningful to them, and to many, those cheering crowds served as a motivating force. Even though many parathletes emphasized individual efforts and responsibilities to achieve sporting success and at times felt insufficient recognition of those efforts, they saw themselves proudly representing their nation.

Finally, activist identity also had high prominence and salience to some parathletes, shaping their sport and life experiences more generally. Some engaged in advocacy through leveraging their recent achievements in Rio, while others have been advocating much longer. Bundon and Clarke (2014) suggested that it would be unfair to expect all Paralympic athletes to assume a role of an advocate in a collective sense. While not many athletes considered activist identity important, none spoke explicitly against advocating for social causes.

The analysis of the prominence and salience of the athletes' multiple identities seems to show that in their social interactions, these individuals strived more often for agency than communion or coherence as their identity-related goals. This finding was evidenced in the accounts of athletic, gender, and disability identities. As discussed earlier, one possible explanation relates to the neoliberal values of individualization and self-responsibility that underpin parathletes' accounts. Meanwhile, in the accounts of national and activist identities, the participants appeared to have attained a balance between achieving their interaction goals and satisfying their identity-related aims for agency, communion, and coherence. A possible explanation here may be that these processes are underpinned by communal values to make a difference and benefit others.

\section{Conclusions}

In this article, the accounts of 41 Brazilian Paralympic athletes offered insight into who they are, how they live their lives, and how they deal with challenges and pursue 
their dreams and aspirations inside and outside sport. The study also discussed how these individuals negotiated their multiple identities in different settings and the tensions they experienced in their social interactions.

In answer to the first research question about how parathletes saw themselves through their different experiences inside and outside Paralympic sport, the analysis of their narratives highlighted different dimensions of their self-representations and the intersection with other identity categories through the lens of the relevant scholarly literature. The result was a more interpretative understanding of identity construction that acknowledges their diverse perspectives. The Paralympians' identity narratives were not always coherent and consistent, and the processes of identity negotiation evidenced tensions between their identity-related goals of agency, communion, and coherence. For example, while sport offered them an empowering view of disability that resisted prevailing stigmas and stereotypes of the impaired body, at the same time, many athletes (female and team sport participants) experienced a lack of recognition and appreciation in sport.

The second insight concerns a nuanced picture of inequality in Paralympic sport and society at large. Collectively, the participants saw themselves as actively attempting to break down barriers and stereotypes, change society's attitudes, and create opportunities for themselves and others. As these athletes showcased their capabilities and actively challenged disability and gender stereotypes, they clashed with the dominant social norms regarding gendered and impaired bodies in sport. However, the strategies of male and female parathletes to deal with society's gender norms were different. Female parathletes did not use sport to overcome disability; they instead integrated their disability into their physicality and built up self-esteem, confidence, and self-efficacy to challenge gender stereotypes and encourage other women to do so. However, most male parathletes saw sport as the path to affirming their masculinity. For this reason, they seemed to downplay their impaired bodies because of the social understanding of disability being undesirable. Moreover, the increasing visibility of these athletes helps to move beyond the notion of the impaired body as a burden (Hargreaves 2000), which may inspire other disabled individuals to engage in sport.

The third insight concerns the personal significance of the Rio Paralympics and its impact on the parathletes' personal experiences. Elite athletes routinely represent their nations in international competitions. For this group, though, representing Brazil in front of thousands of their compatriots intensified the sense of national belonging, pride, and honor, for some for the very first time. Moreover, many athletes commented on the affection of the cheering crowd and an enhanced sense of patriotism in the sporting venues that helped foster a shared sense of national identity and unity with other parathletes and the public.

This article's central theoretical contribution is an interpretative understanding of identity construction and negotiation that acknowledges the voices and stories of Paralympians and highlights the tensions they experienced in their social interactions. I hope to stimulate a debate within research on disability sport and disability studies about how the parathletes' voices and stories can be amplified to pursue positive societal change and affirmative ways of becoming. Moreover, the article's practical contribution is to help policymakers and sport managers devise and enact policies and practices that address inequality in Paralympic sport and outline ways to empower disabled people to get involved in sport on all levels and across a wide range of sports disciplines.

This study has a delimited scope regarding a specific period, geographic boundaries, and targeted group of participants. In addition to this scope delimitation, I discuss two limitations that impact the study's findings: sample profile and financial constraints. First, the study analyzed the narratives of Brazilian Paralympians who competed in the Rio 2016 Games. Including the narratives of retired Paralympians could have revealed different or additional identity features and further illuminate the dynamics of identity construction within and outside sport. Second, financial constraints impacted both the duration and geographic reach of the study. The interviews were conducted shortly after the Rio Paralympics and, to a great extent, reflected the realities of that cycle in terms 
of the parathletes' efforts, expectations, and outcomes. Extending the research duration and collecting data throughout the next Paralympic cycle, Tokyo 2020 and beyond, could yield additional insights. Furthermore, the possibility of travelling with and observing these athletes in the competitive context and other social contexts in Brazil or abroad could contribute to a better understanding of their identity development and the importance of different identity features in different contexts.

The analysis of parathletes' identity construction can be deepened by further research that addresses a more sizeable sample of interviewees targeting retired and active Paralympians, coaches, psychologists, medical professionals, and the National Paralympic Committee leadership, among other stakeholders. Their additional perspectives and experiences may help contribute to the debate on the personal and collective identity construction within Paralympic sport and outline paths to greater equality within the Paralympic movement. Moreover, their views may yield insights for policymakers and practitioners in sport management and sport policies. Future research could also explore in greater depth possible differences between parathlete subgroups (e.g., race, ethnicity, age, social class, sexual orientation, educational background) and introduce new dynamics in the Latin American sport context, including comparative perspectives within the region.

Funding: This research received no external funding.

Institutional Review Board Statement: The study was approved on 19 July 2016 by the Virginia Tech Institutional Review Board, protocol 16-667.

Informed Consent Statement: Informed consent was obtained from all subjects involved in the study.

Acknowledgments: I am grateful to Max Stephenson Jr. and Donna J. Anton for their comments on previous drafts of this paper.

Conflicts of Interest: The author declares no conflict of interest.

\section{References}

Andrews, David L., and Michael L. Silk. 2018. Sport and neoliberalism: An affective-ideological articulation. Journal of Popular Culture 51: 511-33. [CrossRef]

Blauwet, Cheri A. 2015. The Paralympic female athlete. In The Female Athlete. Edited by Margo L. Mountjoy. New York: John Wiley \& Sons, pp. 120-27.

Bochner, Arthur, and Nicholas Riggs. 2014. Practicing narrative inquiry. In The Oxford Handbook of Qualitative Research. Edited by Patricia Leavy. New York: Oxford UP, pp. 195-222.

Braye, Stuart. 2016. "I'm not an activist": An exploratory investigation into retired British Paralympic athletes' views on the relationship between the Paralympic games and disability equality in the United Kingdom. Disability E Society 31: 1288-300. [CrossRef]

Braye, Stuart, Tom Gibbons, and Kevin Dixon. 2017. Disabled athletes as outsiders to English sporting national identity. In Sport and English National Identity in a 'Disunited Kingdom. Edited by Tom Gibbons and Dominic Malcolm. Oxon and New York: Routledge, pp. 125-39.

Brenner, Phillip S., Richard T. Serpe, and Sheldon Stryker. 2014. The causal ordering of prominence and salience in identity theory: An empirical examination. Social Psychology Quarterly 77: 231-52. [CrossRef]

Bundon, Andrea, and Laura H. Clarke. 2014. Honey or Vinegar? Athletes with disabilities discuss strategies for advocacy within the Paralympic Movement. Journal of Sport E Social Issues 39: 351-70. [CrossRef]

Choi, Inhyang, Damian Haslett, and Brett Smith. 2019. Disabled athlete activism in South Korea: A mixed-method study. International Journal of Sport and Exercise Psychology, 1-15. [CrossRef]

Collins, Peter. 2003. Storying self and others: The construction of narrative identity. Journal of Language and Politics 2: 243-64. [CrossRef]

Connell, Robert W., and James W. Messerschmidt. 2005. Hegemonic masculinity: Rethinking the concept. Gender and Society 19: 829-59. [CrossRef]

Cottingham, Michael, Doug Blais, Brian Gearity, Kim Bogle, and Ryan Zapalac. 2015. A qualitative examination of Latin American wheelchair sport practitioner's marketing practices. Journal of Sport for Development 3: 8-19.

Cottingham, Michael, Michael Carroll, Don Lee, Debora Shapiro, and Brenda Pitts. 2016. The historical realization of the Americans with Disabilities Act on athletes with disabilities. Journal of Legal Aspects of Sport 26: 5-22. [CrossRef]

D’Amico, Rosa Lopez, and Tansin Benn. 2016. Latin America: An introduction. In Women and Sport in Latin America. Edited by Rosa Lopez D'Amico, Tansin Benn and Gertrud Pfister. Abington and New York: Routledge, pp. 3-17. 
Darling, Rosalyn B., and D. Alex Heckert. 2010. Orientations toward disability: Differences over the lifecourse. International Journal of Disability, Development and Education 57: 131-43. [CrossRef]

Deal, Mark. 2003. Disabled people's attitudes toward other impairment groups: A hierarchy of impairments. Disability $\mathcal{E}$ Society 18: 897-910. [CrossRef]

De Figueiredo, Rui J. P., Jr., and Zachary Elkins. 2003. Are patriots bigots? An inquiry into the vices of in-group pride. American Journal of Political Science 47: 171-88. [CrossRef]

Downie, Michelle, and Richard Koestner. 2008. Why faster, higher, stronger isn't necessarily better: The relations of Paralympian and women's soccer teams' performance to national well-being. Social Indicators Research 88: 273-80. [CrossRef]

Dworkin, Shari L., and Michael Messner. 2002. Gender relations in sport. Sociological Perspectives 45: 347-52. [CrossRef]

Engel, David M., and Frank W. Munger. 2007. Narrative, disability, and identity. Narrative 15: 85-94. [CrossRef]

Fine, Ben, and Alfredo Saad-Filho. 2017. Thirteen things you need to know about neoliberalism. Critical Sociology 43: 685-706. [CrossRef]

Gard, Michael, and Hayley Fitzgerald. 2008. Tackling Murderball: Masculinity, disability and the big screen. Sports Ethics and Philosophy 2: 126-41. [CrossRef]

Garland-Thomson, Rosemarie. 2002. Integrating disability, transforming feminist theory. NWSA Journal 14: 1-32. [CrossRef]

Garland-Thomson, Rosemarie. 2005. Feminist disability studies. Signs 30: 1557-87. [CrossRef]

Gerschick, Thomas J. 2000. Toward a theory of disability and gender. Signs 25: 1263-68. [CrossRef]

Guedes, Simoni L. 2014. On criollos and capoeiras: Notes on soccer and national identity in Argentina and in Brazil. Soccer $\mathcal{E}$ Society 15: 147-61. [CrossRef]

Guimarães, Cal, Hector Werlang, and Helena Rebello. 2016. Classificação Funcional de Atletas Entra em Xeque às Vésperas da Paralimpíada. Available online: http:/ /globoesporte.globo.com/paralimpiadas/noticia/2016/09/classificacao-funcional-deatletas-entra-em-xeque-vesperas-da-paralimpiada.html (accessed on 11 August 2021).

Hardin, Marie. 2007. "I consider myself an empowered woman": The interaction of sport, gender and disability in the lives of wheelchair basketball players. Women in Sport and Physical Activity Journal 16: 39-52. [CrossRef]

Hargreaves, Jennifer. 2000. Heroines of Sport: The Politics of Difference and Identity. Abingdon and New York: Routledge.

Haslett, Damian, Inhyang Choi, and Brett Smith. 2020a. Para athlete activism: A qualitative examination of disability activism through Paralympic sport in Ireland. Psychology of Sport \& Exercise 47: 101639. [CrossRef]

Haslett, Damian, Javier Monforte, Inhyang Choi, and Brett Smith. 2020b. Promoting para athlete activism: Critical insights from key stakeholders in Ireland. Sociology of Sport Journal 37: 273-82. [CrossRef]

Hilgemberg, Tatiane. 2019. The Brazilian way: Media coverage of the London 2012 Paralympic Games. In Interdisciplinary Approaches to Disability: Looking Towards the Future. Edited by Ellis Katie, Rosemarie Garland-Thomson, Mike Kent and Rachel Robertson. Abingdon and Oxon: Routledge, pp. 266-75. vol. 2.

Hodges, Caroline, Daniel Jackson, and Richard Scullion. 2014. From the distant sidelines: Stories of engagement with the London 2012 Paralympics from disabled people. In Re-Framing Disability? The Media, (Dis)empowerment and Voice in the London Paralympics. Edited by Daniel Jackson, Caroline Hodges, Mike Molesworth and Richard Scullion. London: Routledge, pp. $189-201$.

Howe, P. David. 2011. Cyborg and Supercrip: The Paralympics technology and the (dis)empowerment of disabled athletes. Sociology 45: 868-82. [CrossRef]

Huddy, Leonie. 2016. Unifying national identity research: Interdisciplinary perspectives. In Dynamics of National Identity: Media and Societal Factors of What We Are. Edited by Jürgen Grimm, Leonie Huddy, Peter Schmidt and Josef Seethaler. Abingdon: Routledge, pp. 9-21.

IBGE. 2017. Práticas de Esporte e Atividade Física: 2015. IBGE, Coordenação de Trabalho e Rendimento, Rio de Janeiro. Available online: https: / / biblioteca.ibge.gov.br/visualizacao/livros/liv100364.pdf (accessed on 11 August 2021).

Jefferies, Philip, Pamela Gallagher, and Simon Dunne. 2012. The Paralympic athlete: A systematic review of the psychosocial literature. Prosthetics and Orthotics International 36: 278-89. [CrossRef]

Jenkins, Richard. 2014. Social Identity, 4th ed. New York: Routledge.

Kath, Elizabeth, and Jorge Knijnik. 2015. The End of Football And Fiesta? Social Insurrection And National Identity In Twenty-FirstCentury Brazil. Globalizations 12: 872-85. [CrossRef]

Kaufman, Peter, and Eli A. Wolff. 2010. Playing and protesting: Sport as a vehicle for social change. Journal of Sport E Social Issues 34: 154-75. [CrossRef]

Kavanagh, Emma. 2012. Affirmation through disability: One athlete's personal journey to the London Paralympic Games. Perspectives in Public Health 132: 68-74. [CrossRef]

Kidd, Bruce. 2013. Sports and masculinity. Sport in Society 16: 553-64. [CrossRef]

Le Clair, Jill M. 2011. Transformed identity: From disabled person to global Paralympian. Sport in Society 14: 1116-30. [CrossRef]

Lindemann, Kurt, and James L. Cherney. 2008. Communicating in and through "Murderball": Masculinity and disability in wheelchair rugby. Western Journal of Communication 72: 107-25. [CrossRef]

Malhotra, Ravi, and Morgan Rowe. 2014. Exploring Disability Identity and Disability Rights through Narratives: Finding a Voice of Their Own, 1st ed. Abingdon and Oxon: Routledge.

Manderson, Lenore, and Susan Peake. 2009. Men in motion: Disability and the performance of masculinity. In Bodies In Commotion: Disability \& Performance. Edited by Carry Sandahl and Philip Auslander. Ann Arbor: University of Michigan Press, pp. $230-42$. 
McAdams, Dan P., and Kate C. McLean. 2013. Narrative identity. Current Directions in Psychological Science 22: 233-38. [CrossRef]

McCall, George J., and Jerry L. Simmons. 1978. Identities and Interactions: An Examination of Human Associations in Everyday Life. New York: Free Press.

Meier, Marianne. 2015. The value of female sporting role models. Sport in Society 18: 968-82. [CrossRef]

Messner, Michael A. 1992. Power at Play: Sports and the Problem of Masculinity. Westminster and Boston: Beacon Press.

Nolan, Maeve. 2013. Masculinity lost: A systematic review of qualitative research on men with spinal cord injury. Spinal Cord 51: 588-95. [CrossRef]

O Fuxico. 2014. Fernando Fernandes Denuncia 'Falsos' Atletas que Disputam as Paraolimpíadas. August 27. Available online: http:/ / www.ofuxico.com.br/noticias-sobre-famosos/fernando-fernandes-denuncia-falsos-atletas-que-disputam-asparaolimpiadas/2014/08/27-213433.html (accessed on 11 August 2021).

Olenik, Lisa M., Joan M. Matthews, and Robert D. Steadward. 1995. Women, disability and sport: Unheard voices. Canadian Woman Studies 15: 54-73.

Ortiz, Renato. 2013. Imagens do Brasil [Images of Brazil]. Sociedade e Estado 28: 609-33. [CrossRef]

Pack, Stephen, Sasha Kelly, and Monna Arvinen-Barrow. 2017. “I think I became a swimmer rather than just someone with a disability swimming up and down:" Paralympic athletes perceptions of self and identity development. Disability and Rehabilitation 39: 2063-70. [CrossRef] [PubMed]

Peers, Danielle. 2009. (Dis)empowering Paralympic histories: Absent athletes and disabling discourses. Disability E Society 24: 653-665. [CrossRef]

Purdue, David, and P. David Howe. 2012. See the sport, not the disability: Exploring the Paralympic paradox. Qualitative Research in Sport, Exercise and Health 4: 189-205. [CrossRef]

Richard, Remi, Helen Joncheray, and Eric Dugas. 2017. Disabled sportswomen and gender construction in powerchair football. International Review for the Sociology of Sport 52: 61-81. [CrossRef]

Rodrigues, Carolina A. 2015. A Mulher Atleta: Feminilidade e Desvalorização. Uma Breve Revisão. EFDeportes.com, Revista Digital 19(201). Available online: http:/ / www.efdeportes.com/efd201/a-mulher-atleta-feminilidade-e-desvalorizacao.htm (accessed on 11 August 2021).

Rubio, Katia, Helena Altmann, Ludmila Mourão, and Silvana Goellner. 2016. Women and sport in Brazil. In Women and Sport in Latin America. Edited by Rosa L. D'Amico, Tansin Benn and Gertrud Pfister. Abington and New York: Routledge, pp. 69-78.

Ruddell, Jennifer L., and Kimberly J. Shinew. 2006. The socialization process for women with physical disabilities: The impact of agents and agencies in the introduction to an elite sport. Journal of Leisure Research 38: 421-44. [CrossRef]

Seal, Emma L. 2014. Juggling Identities: Elite Female Athletes' Negotiation of Identities in Disability Sport. Ph.D. Thesis, University of Bath, Bath, UK.

Shuttleworth, Russel, Nikki Wedgwood, and Nathan J. Wilson. 2012. The dilemma of disabled masculinity. Men and Masculinities 15: 174-94. [CrossRef]

Silva, Carla F., and P. David Howe. 2012. The (in)validity of supercrip representation of Paralympian athletes. Journal of Sport $\mathcal{E}$ Social Issues 36: 174-94. [CrossRef]

Silverman, Arielle M., and Geoffrey L. Cohen. 2014. Stereotypes as stumbling-blocks: How coping with stereotype threat affects life outcomes for people with physical disabilities. Personality and Social Psychology Bulletin 40: 1330-40. [CrossRef] [PubMed]

Smith, Brett, Andrea Bundon, and Melanie Best. 2016. Disability sport and activist identities: A qualitative study of narratives of activism among elite athletes with impairment. Psychology of Sport \& Exercise 26: 139-48. [CrossRef]

Stevenson, Dale. 2010. Paralympic Masculinities: Media and Self-Representation of Athletes at the 2008 Paralympic Summer Games. Master's Thesis, University of Manitoba, Winnipeg, MB, Canada.

Swain, John, and Sally French. 2000. Towards an affirmation model of disability. Disability E Society 15: 569-82. [CrossRef]

Swann, William B., Jr., and Jennifer K. Bosson. 2008. Identity negotiation: A theory of self and social interaction. In Handbook of Personality: Theory and Research, 3rd ed. Edited by Oliver P. John, Richard W. Robins and Lawrence A. Pervin. New York: Guilford Press, pp. 448-71.

Thomas, Nigel, and Andy Smith. 2009. Disability, Sport and Society: An Introduction. London: Routledge.

Wendell, Susan. 1989. Toward a feminist theory of disability. Hypatia 4: 104-24. [CrossRef] [PubMed] 